\title{
ESCRITOS DE GUERRA DE CLARICE LISPECTOR
}

\author{
Aparecida Maria Nunes * \\ Nataly Ternero ${ }^{* *}$
}

RESUMO: Este artigo se propõe a analisar a correspondência de Clarice Lispector trocada com familiares e amigos entre os anos 1944 e 1946, enquanto a autora morava em Nápoles, Itália, assim como as crônicas escritas por ela sobre o período da Segunda Guerra Mundial. Pretende-se, com este estudo, identificar o pano de fundo histórico no qual a autora esteve inserida durante sua passagem pela Itália e as dimensões subjetivas de sua interrelação com o ambiente à sua volta: ser uma jovem estrangeira de descendência judaica em meio à guerra nazista, longe de família e amigos. Buscou-se, assim, compreender quais representações de Europa e de guerra foram construídas tanto na correspondência pessoal da autora quanto em seus textos publicados posteriormente à sua estadia no estrangeiro.

PALAVRAS-CHAVE: Clarice Lispector; Correspondência; Crônicas; Segunda Guerra Mundial.

\section{Clarice em movimento}

Clarice Lispector saiu do Brasil pela primeira vez em 30 de julho de 1944, deixando a cidade do Rio de Janeiro, depois de passar seis meses em Belém, rumo à Itália, primeiro país a receber a escritora em sua peregrinação no estrangeiro que duraria quase dezesseis anos. Seu marido, Maury Gurgel Valente, que a escritora conheceu no curso de Direito, frequentado por ambos, havia se empossado do cargo de vice-cônsul, fato esse que exigiu que o casal se mudasse para a cidade de Nápoles.

A escritora, que perdeu cedo mãe e pai, era muito apegada a suas irmãs mais velhas, Elisa e Tania. Clarice era também extremamente ligada ao Brasil, principalmente às cidades de Recife - na qual ela passou a infância e que a acompanharia para o resto da vida em suas lembranças mais ternas - e Rio de Janeiro, onde viveu a mocidade e começo da vida adulta, criando laços de amizade, de trabalho e de literatura.

\footnotetext{
* Professora da Universidade Federal de Alfenas (Unifal). Doutora em Letras pela Universidade de São Paulo (Usp). Realizou estágio pós-doutoral em Estudos Literários na Universidade Federal de Minas Gerais (UFMG).

** Mestranda em Letras Estrangeiras e Tradução pela Universidade de São Paulo (Usp).
} 
Apesar da origem eslava, Clarice nunca se identificou como tal, e sim como inteiramente brasileira, arraigada à cultura e em especial à língua do Brasil. A carta de 3 de junho de 1942 a Getúlio Vargas, presidente naquele período, deixa evidente a identidade da jovem escritora que solicita que lhe seja concedida a nacionalidade brasileira para poder se casar com Maury Gurgel Valente e explica:

Quem lhe escreve é [...] uma russa de 21 anos de idade e que está no Brasil há 21 anos menos alguns meses. Que não conhece uma só palavra de russo mas que pensa, fala, escreve e age em português, fazendo disso sua profissão e nisso pousando todos os projetos do seu futuro. [...] Que, se fosse obrigada a voltar à Rússia, lá se sentiria irremediavelmente estrangeira, sem amigos, sem profissão, sem esperanças. [...] Demonstrei minha ligação com esta terra e meu desejo de servi-la, cooperando com o DIP, por meio de reportagens e artigos, distribuídos aos jornais do Rio e dos estados, na divulgação e na propaganda do governo de V. Ex. ${ }^{a}$. E, de um modo geral, trabalhando na imprensa diária, o grande elemento de aproximação entre governo e povo. [...] Posso apresentar provas materiais de tudo o que afirmo. Infelizmente, o que não posso provar materialmente e que, no entanto, é o que mais importa - é que tudo que fiz tinha como núcleo minha real união com o país e que não possuo, nem elegeria, outra pátria senão o Brasil. (LISPECTOR, 2002, p. 33-34)

Clarice afirmou sentir-se totalmente brasileira, e não possuir outra pátria senão esta. Por essas razões, partir para o estrangeiro e deixar a terra na qual finalmente se sentia pertencente, rumo ao desconhecido, foi extremamente doloroso para ela - ainda mais por não viajar por razões próprias, e sim pela obrigação social de seguir o marido em suas missões diplomáticas, vida tão divergente dos valores pessoais da jovem.

O excerto de carta citada traz ainda informações interessantes, como a ligação de Clarice ao Departamento de Imprensa e Propaganda (DIP) do governo Vargas, no qual ingressou em 1940. Como a estudiosa Berta Waldman discute em seu artigo "Por linhas tortas: o judaísmo em Clarice Lispector":

É importante lembrar que ela se fixa nesse emprego durante o Estado Novo, tendo esse órgão oficial de informação sido criado por Getúlio Vargas, em 1934, subordinado ao Ministério da Justiça e 
Negócios Interiores. Nesse período o nazi-fascismo ${ }^{1}$ recrudescia na Europa, Hitler já estava no poder, as leis raciais vigiam, e os campos de concentração logo seriam ativados, motivando o deslocamento geral de judeus, com seus passaportes marcados, tentando migrar para outros países. (WALDMAN, 2011, p. 2)

A ligação de Lispector ao Brasil era intensa e verdadeira; entretanto, é necessário ressaltar que o anseio da jovem em ser reconhecida como brasileira pode ser entendido também como um mecanismo de defesa, já que ser vista como eslava e judia no momento histórico no qual vivia poderia acarretar consequências sérias. É o que defende Waldman, que argumenta consistir em "um problema complexo ser judeu nesse período e compreende-se que Lispector desejasse de algum modo ser completamente brasileira e ser vista enquanto tal". (WALDMAN, 2011, p. 2).

Os coquetéis, jantares de negócios e a necessidade de manter as aparências iam de encontro às convicções da Clarice de 24 anos $^{2}$, tão avessa a representações, a teatros. Podese notar essa divergência no trecho a seguir, retirado da carta de 19 de agosto de 1944, enviada de $\mathrm{Argel}^{3}$, cidade pela qual passou enquanto estava a caminho de $\mathrm{Nápoles}^{4}$, para as irmãs:

Eu acho graça em ouvi-las [as pessoas] falar de nobrezas e aristocracias e de me ver sentada no meio delas, com o ar + gentil e delicado que eu posso achar. Nunca ouvi tanta bobagem séria e irremediável como nesse mês de viagem. Gente cheia de certezas e de julgamentos, de vida vazia e entupida de prazeres sociais e delicadezas. (LISPECTOR, 2002, p. 51)

Em $1^{\circ}$ de setembro de 1945, em carta enviada de Nápoles, mais de um ano após a carta acima, o tom irônico de Clarice ao referir-se às convenções sociais continuava o mesmo:

\footnotetext{
${ }^{1}$ Em todas as citações deste trabalho, manteve-se a ortografia como no original consultado.

2 Além de Nápoles, Clarice Lispector viveria em Berna, na Suíça (talvez o destino mais criticado por ela em suas correspondências), em Torquay, Inglaterra e em Washington, Estados Unidos, voltando a viver definitivamente no Brasil somente em 1959, já separada de Maury.

${ }^{3}$ Sobre Argel, Clarice comentou na mesma carta, evidenciando o impacto da guerra na região: "A cidade não tem muita marca oriental, é cheia de soldados americanos, franceses e ingleses." (LISPECTOR, 2002, p. 49).

${ }^{4}$ Em Nápoles, Clarice Lispector chega em final de agosto de 1944 e permanece na cidade italiana até abril de 1946, quando, então, muda-se para Berna.
} 
Os embaixadores me respeitam... As pessoas me acham "interessante"... Eu concordo com tudo, também, nunca discordo do que se diz, tenho muito tato e conquisto as pessoas necessárias. Como você vê, sou uma boa senhora de diplomata. (LISPECTOR, 2007, p. 94)

A Europa sentida pela Clarice viajante estava em ebulição e em contradição com a vida que até então tinha tido no Brasil: jantares luxuosos, consumismo em lojas diversas e exuberantes, viagens de passeio em pontos turísticos dos países por ela visitados. Mesmo estando a poucos meses do fim da guerra, os relatos de Clarice não mencionam histórias de judeus ou de angústias dos napolitanos perante o conflito bélico. Há uma outra Itália que aparece na maior parte em passeios, fotografias, recepções pomposas. É raro o olhar que desnuda as ruas, como nesta passagem:

É verdade que se culpa a guerra de muita coisa que sempre existiu aqui. A prostituição, por exemplo, sempre foi aqui um grande meio de vida. Contam-nos que agora os meninos na rua oferecem as irmãs, o marido que diz que tem uma moça muito bonita e no fim sabe-se que é a mulher dele, etc; mas todos dizem que é isso sempre. Tem aqui é que o povo napolitano é o + sem-vergonha do mundo. Os italianos dizem que a vergonha da Itália é Nápoles. Roubam como podem, e não sou quem os acusaria. [...] A guerra é boa talvez no sentido de chamar a atenção para certos problemas. Talvez incorporem estes na resolução de outros propriamente de guerra. (LISPECTOR, 2007, p. 69) ${ }^{5}$

As condições precárias nas quais os napolitanos viviam durante (e, segundo a própria, também antes) o período de guerra saltavam aos olhos de Clarice. Mas ela não se demora nesses registros, apesar de acreditar que o período de guerra tinha essa particularidade de escancarar ao mundo problemas antigos da região.

O período vivido em Nápoles não foi expressivo para Lispector em termos de produção literária. Consegue finalizar, em novembro de 1944, O lustre (1946), que havia começado no Brasil, mesmo antes de escrever Perto do coração selvagem (1943). Mas foi fértil em 
reflexões pessoais, troca de cartas e em experiências de vida que os rituais diplomáticos a introduziram.

Nesse contexto, mostra-se relevante comentar a entrevista concedida pela autora ao jornal $A$ manhã, do Rio de Janeiro, edição de 2 de dezembro de 1945, com o fim da guerra e enquanto ela ainda morava na Itália. Clarice foi entrevistada por Solena Benevides Viana e questionada sobre o cenário literário na Itália da época, ao que respondeu, com cautela, segundo a entrevistadora:

Lamento não poder dar muitas informações sobre a situação literária na Itália e na Europa em geral, o que certamente mais interessa a qualquer leitor. Todo o ambiente durante esse meu ano de Itália tendo sido de guerra, e eu mesmo estando afastada dos meios literários, torna-se difícil dar-lhe noções mais precisas sobre o que acontece nesse setor. (VIANA, 1945, p. 1)

Percebe-se que, apesar do interesse da imprensa brasileira em colher notícias atualizadas sobre o conflito mundial, mesmo sob a censura do Estado Novo, as informações custavam a circular. Havia muitas incertezas e tudo era muito vago, pelo testemunho de Clarice Lispector, que continuou a esclarecer:

Não tendo estado em contato com escritores de um modo geral, e é difícil dada a perturbação do momento, chegar a uma conclusão. Editam-se aqui muito livros antigos, fazem-se inúmeras traduções da melhor qualidade. Quanto a um movimento literário italiano, parece-me que há um interesse especial pelo romance social; é do que se ocupam os mais jovens. Mesmo durante o fascismo havia essa tendência, velada, nos romances, o que a censura permitia por não compreender. [...] Em relação a uma surpresa literária no mundo de após-guerra, nada notei que me fizesse esperá-la; essa surpresa virá amanhã ou daqui a cem anos. É provável que venha amanhã, não sei. ${ }^{6}$ (VIANA, 1945, p. 1)

\footnotetext{
${ }^{6} \mathrm{Na}$ palestra que Clarice proferiu no XI Congresso Bienal do Instituto Internacional de Literatura Ibero-Americana da Universidade do Texas que ocorreu entre 29 e 31 de agosto de 1963, a escritora falaria sobre sua experiência intelectual e literária no mesmo tom que utilizou na entrevista de 1945: "por circunstâncias internas e externas, não posso dizer que tenha acompanhado de perto a efervescência dos movimentos que surgiram e das experiências que se tentaram, quer no Brasil, quer fora do Brasil. Nunca tive, enfim, o que se chama verdadeiramente de vida intelectual." (LISPECTOR, 2005, p. 76).
} 
Observa-se, no comentário acima, o isolamento literário e intelectual vivido por Clarice na Itália, assim como "a perturbação do momento", que não era propícia à criação artística. O romance social, segundo ela, estava em voga, ocorrência para a qual o ambiente de guerra colaborava. Lispector chamou atenção para o fato de o romance social ser uma possível saída para a censura fascista, que acabava por não conseguir ler nas entrelinhas e compreender as críticas feitas ao sistema político. A escritora especulou, ainda, sobre o futuro da literatura após a guerra e as influências que viriam com ela, além de mencionar o nome de Jean-Paul Sartre que se sobressaía em importância.

Ainda nessa entrevista de $A$ manhã, Viana questionou a escritora se o "longo período de luta armada que finalizou terá influído decisivamente na literatura brasileira, abrindo-lhe novos horizontes". Clarice, considerando que a guerra, naturalmente, teria influência não somente na literatura brasileira, como nas demais, explicou que se revelaram "várias realidades, criaram-se muitas novas. Desses dois fatos e da consciência deles podem nascer novos rumos".

Recém-descoberto prodígio literário no Brasil quando precisou deixar o país, a jovem Clarice viu-se deslocada de seu meio cultural e alienada da sociedade intelectual brasileira (e também da estrangeira). Mesmo escrevendo, quando possível, foi difícil para a escritora manter-se a par dos movimentos literários ao seu redor, devido tanto a seus constantes deslocamentos, quanto à atmosfera de caos.

Portanto, as dinâmicas vivenciadas pela autora na Europa dos meados do século $\mathrm{XX}$, permeadas pelo contato com a desigualdade social e com a guerra, impactariam tanto a vida pessoal de Clarice como seus escritos futuros, o que se pretende demonstrar a seguir.

\section{Escritos antituristas: as cartas}

Uma das características de Clarice Lispector evidenciada pela leitura de sua correspondência é seu "antiturismo"; o mundo todo parece igual a ela, em toda parte as pessoas têm os mesmos dilemas e fazem as mesmas coisas.

Assim, mesmo fazendo grandes viagens, visitando pontos turísticos e tão diversas cidades (como Lisboa, Argel e Roma), Clarice não se deixava impressionar pela 
grandiosidade do mundo, sentindo-o tão igual em toda parte, e tentava transmitir para seus destinatários as impressões pessoais daqueles lugares, díspares dos "roteiros de excursões".

Em carta de 7 de agosto de 1944 às irmãs Tania e Elisa, enviada de Lisboa, onde Clarice passou alguns dias antes de finalmente aterrissar em Nápoles, ela comenta:

Não estou tendo prazer em viajar. Gostaria de estar aí com vocês ou com Maury. O mundo todo é ligeiramente chato, parece. O que importa na vida é estar junto de quem se gosta. Isso é a maior verdade do mundo. E se existe um lugar especialmente simpático é o Brasil. [...] É chatíssimo não morar. (LISPECTOR, 2007, p. 40-41)

Privada, por diversas vezes, da companhia do marido, que se ausentava para seus compromissos oficiais (no período no qual a carta acima foi enviada, Maury havia partido antes da esposa para Nápoles, com o objetivo de organizar a estadia do casal na cidade e participar de reuniões), Clarice demonstrou sua solidão para as irmãs, afirmando preferir a rotina da vida brasileira ao luxo das viagens internacionais para lugares de cartão postal. Queixou-se, ainda, sobre como era aborrecido não morar em nenhuma parte, e estar sempre vivendo como hóspede.

Para Clarice, a guerra significou principalmente o cerceamento de sua liberdade de ir e vir, retardando sua tão ansiada volta ao Brasil. A dificuldade em manter correspondência também foi uma das mudanças na rotina de Clarice decorrentes do estado de guerra. Como ela mesma mencionou em carta de 19 de agosto de 1944 para suas irmãs: "É quase certo que durante algum tempo não poderei escrever, por condições de Nápoles mesmo" (LISPECTOR, 2002, p. 52). Na mesma carta, entretanto, Clarice tranquilizou a família ao dizer que

[...] as coisas lá [em Nápoles] não estão tão difíceis assim [...]. Agora os americanos devem ter melhorado ainda mais. Não nos faltará nada, estou certa, principalmente em relação à comida por causa dos americanos que nos auxiliarão certamente. (LISPECTOR, 2002, p. 50)

A autora chegou inclusive a comentar que não lhe faltaria nada, "nem mesmo batons porque Roma é perto” (LISPECTOR, 2002, p. 52). 
É especialmente reveladora a já mencionada carta de setembro de 1944 enviada ao amigo Lúcio Cardoso. O texto foi escrito por Clarice logo após sua chegada a Nápoles e inclui opiniões frescas sobre a cidade e seus habitantes. Ela iniciou a carta dizendo ser estranho escrever "de tão longe", porque "parece que se fica com a obrigação de dizer coisas formidáveis", ao que conclui: "nada é formidável, ou sei lá, talvez tudo seja" (LISPECTOR, 2002, p. 54).

Essa indiferença, acompanhada pela sensação de não estar absorvendo tudo o que deveria, são constantes na correspondência clariciana. Em outro trecho dessa mesma carta, ela diz: "Nunca vi ninguém menos turista", referindo-se a si mesma.

Sua chegada à Itália foi pela cidade de Taranto, em transportes oficiais dos funcionários públicos, fazendo ali uma escala para o destino final - Nápoles. O percurso todo foi cansativo, tanto física quanto mentalmente:

[...] fui de navio, já então com dr. Vasco Leitão da Cunha e meu cunhado que trabalha com ele, até Taranto, sem largar um instante o salva-vidas obrigatório, comboiada nos dois destróieres. Em Taranto tomamos o avião particular do comandante em chefe das forças aliadas no Mediterrâneo e chegamos a esta cidade [Nápoles]. Eu estava moralmente exausta [...]. (LISPECTOR, 2002, p. 55-56)

As impressões geradas pela cidade de Nápoles em Clarice foram em seguida externalizadas ao interlocutor Lúcio, como se lê a seguir:

Isso aqui é lindo. É uma cidade suja e desordenada, como se o principal fosse o mar, as pessoas, as coisas. As pessoas parecem morar provisoriamente. E tudo aqui tem uma cor esmaecida, mas não como se tivesse um véu por cima: são as verdadeiras cores. Um edifício novo aqui tem um ar brutal. Às vezes eu me sinto ótima; às vezes simplesmente não vejo nada, não sinto nada. (LISPECTOR, 2002, p. 56)

A Nápoles vista pela primeira vez por Lispector lhe pareceu um lugar transitório e obscuro. Como que projetando os próprios sentimentos nos moradores da cidade, Clarice talvez também entediada pelo clima da guerra que se alongava, e já em processo da angústia que a cometeria durante os três anos em Berna, sentia-se desterrada, não pertencia àquele lugar. O estupor a perseguia: “às vezes simplesmente não vejo nada, não sinto nada”. Era 
uma exilada, mesmo pedindo para que Lúcio Cardoso não a considerasse assim: "Não me esqueça inteiramente, Lúcio, não me considere exilada. A distância nada quer dizer, acredite" (LISPECTOR, 2002, p. 57).

Em 21 de novembro de 1944, Clarice queixou-se nos mesmos termos às irmãs em carta, dizendo: "Eu sou uma pobre exilada. Você não imagina como longe do Brasil se tem saudade dele. Sou capaz de escrever um novo Brasil, país do futuro...” (LISPECTOR, 2007, p. 63). Fazendo referência à obra do escritor austríaco Stefan Zweig lançada três anos antes, a ficcionista externalizou mais uma vez sua nostalgia, vendo-se privada do convívio em sua terra "natal". Privação essa que se acentuava por uma vida dentro de casa, ou melhor, dentro do quarto, o que lhe agradava (o casal estava morando no Consulado), segundo confessa novamente em carta às irmãs. (LISPECTOR, 2007, p. 55)

A ânsia por romper com esse "voluntário" exílio e retornar ao Brasil para poder reencontrar-se com a família aparece em diversas cartas escritas pela autora a suas irmãs, como destaca-se no seguinte trecho:

Depois da guerra, é certíssimo que eu vou aí passar um mês ou dois. Mas mesmo agora andei pedindo e sondando junto de várias pessoas e a coisa é difícil, quase impossível. Espero tremendamente que a guerra acabe, por todos os motivos. E o que é mais egoísta é esse, o de permitir que eu faça essa viagem. [...] Deixo apenas que acabe essa maldita guerra, que para nós felizmente não foi tão maldita. (LISPECTOR, 2007, p. 64)

Em meio às súplicas por voltar ao Brasil, Clarice pareceu querer tranquilizar as irmãs ao dizer que a guerra, para o casal, "não foi tão maldita". Tanto que algumas linhas depois, ela discorreu sobre a situação dos moradores de Nápoles, contrastante com a deles: “O povo vive claramente em contrabando, mercado negro, prostituição, assaltos e roubo". (LISPECTOR, 2007, p. 65). O apelo por reencontrar-se com a família pelo encerramento do estado de guerra continua em outra carta, desta vez a Elisa7: "Em suma, a ideia do Brasil 
é muito boa para mim. Que esse diabo de guerra acabe é o que eu desejo" (LISPECTOR, 2007, p. 67).

Na carta seguinte à de setembro de 1944, também dirigida a Lúcio Cardoso, porém incompleta, Clarice se queixou de seu estado de espírito ao amigo, o que permite avaliar o estado emocional em que se encontrava, esgotada: "Não consigo lhe dar a ideia do que é isto aqui. Nem de mim mesma. Não sei o que está me fazendo triste e cansada” (LISPECTOR, 2002, p. 58). Parecia cansada de representar um papel, de socializar com pessoas tão diferentes e sobre assuntos que a consumiam mentalmente, de ver-se privada da convivência com as pessoas amadas no Brasil, como transparece no final dessa mesma carta: "Enquanto vocês vivem no Brasil, eu aqui tomo chá com leite num colégio de moças" (LISPECTOR, 2002, p. 59).

O fato de viver "em suspenso", morando no Consulado do Brasil em Nápoles, que não era um lar, também colaborou para a sensação de não pertencimento de Clarice, que comentou para Cardoso:

Continuamos morando todos no Consulado; em parte é bom porque me tira a responsabilidade de pensar em casa. Mas nós bem gostaríamos de estar num apartamento nosso. Embora se possa com esforço arranjar para não ter uma vida por demais misturada com a dos outros. (LISPECTOR, 2002, p. 58)

Era, de certa maneira, bom não precisar preocupar-se com as tarefas domésticas de uma "casa" que não era sua, mas a falta de privacidade e de acolhimento para os jovens recém-casados pode ser vista como uma das causas desse constante cansaço e da quase sempre presente melancolia na Clarice dessa época. Em 13 de novembro de 1944, em carta à irmã Elisa, o assunto é retomado: "Continuamos morando no consulado. Minhas atividades de dona de casa são nulas, felizmente. Eu não decido nada e só às vezes me meto, porque senão tudo cairia em cima de mim [...]” (LISPECTOR, 2007, p. 58).

Na mesma carta acima citada, Clarice compartilhou com a irmã um "causo" de guerra, por ela ouvido:

Lembrei-me de uma coisa engraçada. O primeiro escalão de soldados brasileiros inventou um sambinha a bordo do navio (eles inventam mil). Era sobre o nabisco: nabisco é uma espécie de bolacha americana, dura, que, embebida em leite, fica mole; serviam isso no 
breakfast e os soldados, acostumados com a caneca de café e o pão com manteiga, ficavam danados. Fizeram o seguinte samba:

De covarde podem me chamar,

O fato é que já passei o Gibraltar.

Este "shiipe" pode até afundar,

O que eu quero ver é o nabisco boiar. (LISPECTOR, 2007, 59)

De acordo com o pesquisador Luciano Bastos Meron, em sua tese Memórias do front: relatos de guerra de veteranos da FEB, "atitudes jocosas, o canto e o samba apareceriam como estratégias para lidar com o medo e com o stress" (MERON, 2009, p. 48), dinâmicas que podem ser observadas nas lembranças registradas por Clarice Lispector.

Um dos acontecimentos mais interessantes descobertos com a leitura de sua correspondência é a contribuição da própria Clarice às Forças Expedicionárias Brasileiras. Como seu marido e ela não podiam ajudar financeiramente os soldados e a instituição, a escritora se voluntariou para colaborar com sua força de trabalho, atuando na Seção de Serviço Social de Saúde. No excerto abaixo da carta de 12 de janeiro de 1945, Clarice descreve as funções por ela exercidas:

Porque me ofereci para fazer alguma coisa, estou trabalhando em datilografia com o coronel Julio de Moraes. Vou lá todas as manhãs e salvo a humanidade copiando numa letra linda à máquina, umas coisas. Pretendo também visitar feridos. Ajudamos pessoalmente e em cada caso como podemos e isso não é nada. Os casos aqui são inúmeros e cada família tem o que contar. (LISPECTOR, 2007, p. 69)

Lispector conversava com os feridos e batia à máquina cartas que eles a ditavam. As condições precárias em que as famílias da cidade se encontravam ficam evidentes pela descrição da autora, que tentou ajudar como pôde, mesmo com a sensação de que suas ações não eram suficientes. Em carta a Lúcio Cardoso escrita em 26 de março de 1945, Clarice detalhou seu trabalho voluntário e falou ainda sobre o sentimento de empatia e de ajuda mútua que os doentes lhe despertaram:

Estou trabalhando no hospital americano, com os brasileiros. Visito diariamente todos os doentes, dou o que eles precisam, converso, discuto com a administração pedindo coisas, enfim sou formidável. 
Vou lá todas as manhãs e quando sou obrigada a faltar fico aborrecida, tanto os doentes já me esperam, tanto eu mesma tenho saudade deles. (LISPECTOR, 2002, p. 70)

Sentir-se útil, ocupar-se, era extremamente importante para Clarice naquele contexto, ainda mais por saber que ela estava em condições melhores do que seus compatriotas militares. Como ela contou em carta de 19 de março às irmãs: "Continuo trabalhando no hospital indo lá todas as manhãs. Me canso um pouco, mas corpo e alma foram feitos para na hora de dormir estarem cansados" (LISPECTOR, 2007, p. 76-77). Dessa maneira, Lispector criou laços de dependência mútua com os feridos, auxiliando-os como podia e sendo por eles ajudada a seguir alguma rotina durante a situação de guerra na qual se encontrava.

Por seus serviços prestados, a escritora recebeu um ofício de agradecimento do Chefe da Seção Brasileira de Hospitalização em Nápoles, que a "emocionou um pouco, sobretudo porque eu não imaginava a possibilidade de recebê-lo” (LISPECTOR, 2007, p. 84):

Ao deixar a Chefia da Seção Brasileira de Hospitalização em Nápoles, cumpro o grato dever de agradecer a V. Excia. todo o serviço que tão espontaneamente vem prestando a nossa organização, colaborando na sua Secção de Serviço Social, trazendo ao nosso soldado ferido ou doente o grande consolo do seu serviço e da sua graça. Nunca seriam demais as palavras que eu poderia dirigir a V. Ex. para expressar a minha admiração pela contribuição que trouxe a todos nós nestes momentos em que o Brasil precisa tanto de seus filhos. Em nome destes homens, de todos os que aqui labutam e no meu próprio, beijo, agradecido, as vossas mãos dadivosas. Nápoles, 17abril-1945- Dr. Sette Ramalho, Tte. Coronel Médico. (LISPECTOR, 2007, p. 84)

Quando, em 9 de maio de 1945, Clarice finalmente pôde dar a tão esperada notícia a suas irmãs - o fim da guerra -, o êxtase que pensava que viria desse acontecimento não foi tão forte como ela imaginava:

Uma das coisas de que estou surpreendida e vocês certamente também é que no bilhete de hoje de manhã não falei do fim da guerra. Eu pensava que quando ela acabasse eu ficaria alguns dias zonza. O fato é que o ambiente influiu muito nisso. Aposto que no Brasil a alegria foi maior. Aqui não houve comemorações senão feriado ontem; é que veio tão lentamente esse fim, o povo está tão cansado 
(sem falar que a Itália foi de algum modo vencida) que ninguém se emocionou demais. (LISPECTOR, 2002, p. 73)

Percebe-se, com a narração de Clarice, que a guerra foi tão longa que era difícil acreditar que ela realmente havia acabado. A escritora chegou a imaginar que a alegria deveria ter sido mais intensa no Brasil, país um pouco mais afastado dos impasses da guerra, do que para aqueles diretamente ligados a ela. Para quem a experienciava diariamente, como o povo vivendo em Nápoles, não era fácil esboçar alegria, surpresa.

$\mathrm{Na}$ mesma carta, Clarice seguiu descrevendo o momento em que todos ficaram sabendo do fim da guerra; curiosa é a narração da reação do famoso pintor italiano De Chirico, para quem ela posava no momento em que soube da notícia:

Eu estava posando para De Chirico quando o jornaleiro gritou: $E^{\prime}$ finita la guerra! Eu também dei um grito, o pintor parou, comentouse a falta estranha de alegria da gente e continuou-se. Daqui a pouco eu perguntei se ele gostava de ter discípulos. Ele disse que sim e que pretendia ter quando a guerra acabasse... Eu disse: mas a guerra acabou! Em parte a frase dele vinha do hábito de se repeti-la, e em parte do fato de não ter mesmo a impressão exata de um alívio. (LISPECTOR, 2002, p. 73-74)

Como comentado acima, o povo italiano estava de tal modo atrelado à espera de que a guerra acabasse que, quando isso realmente aconteceu, demorou-se a compreender o fato. De Chirico, como se percebe pelo texto de Clarice, "acostumou-se" a postergar as decisões importantes e as mudanças de rotina para esse "depois da guerra", e ficou sem reação quando esse momento chegou.

Em carta de 22 de agosto a Elisa Lispector, Clarice disse que "o fim da guerra no mundo abalou os italianos: ninguém ligou muito, não houve festejos, nem alegria. Essa ‘terra dos artistas' está meio indiferente, ao que parece” (LISPECTOR, 2007, p. 92) Na carta seguinte à essa, escrita em $1^{\text {o }}$ de setembro de 1945, Clarice tentou fugir do tom melancólico da narração para a irmã Tania, logo admitiu ser difícil, como se lê a seguir:

$\mathrm{Na}$ verdade não tenho ido a festas, que Nápoles tem pouca vida social. Tudo o que eu tenho é a nostalgia que vem de uma vida 
errada, de um temperamento excessivamente sensível [...]. (LISPECTOR, 2002, p. 75)

A nostalgia, a sensibilidade e a solidão continuavam presentes nas falas de Clarice, mesmo quase depois de um ano de vivência em Nápoles.

As cartas escritas por Clarice Lispector para seus familiares e amigos mostram-se vasto material para pesquisa, tanto das vivências e do contexto sócio-histórico da escritora, quanto de um panorama maior dos intelectuais brasileiros direta ou indiretamente afetados pela Segunda Guerra Mundial.

\section{Momentos recortados: as crônicas}

Quando retornou definitivamente ao Brasil, em 1959, separada do marido e mãe de dois filhos, Clarice sentiu dificuldade em realocar-se na vida literária brasileira, e encontra no trabalho midiático uma forma de sobrevivência. No período de 1967 a 1973, o carioca Jornal do Brasil, mediante proposta do amigo jornalista Alberto Dines, publica crônicas da escritora no Caderno B em coluna semanal aos sábados. Nesse espaço, os escritos subvertem muitas vezes ao gênero da coluna, que também acolhe entrevistas, contos, sensações, comentários e fragmentos de futuras obras. Lispector retoma vivências pessoais, acontecimentos e pensamentos, "segredando-os" aos leitores do jornal.

Parte de sua produção durante os sete anos de contribuição ao Jornal do Brasil foi posteriormente reunida no volume $A$ descoberta do mundo, publicado pela primeira vez em 1984. Dessa coletânea, algumas crônicas são sintomáticas e trazem memórias do período em que a escritora residiu em Nápoles, "O maior elogio que já recebi” (1968), "Você é um número" (1971), "Bichos (I)" e "Bichos (Conclusão)" (ambas de 1971) e “Aldeia nas montanhas da Itália” (1972).

“O maior elogio que já recebi”, publicada em 1968 no Jornal do Brasil, rememora uma fala escutada por Clarice durante sua passagem por Nápoles, reelaborada anos depois por ela neste texto introspectivo que transpõe "para dentro" um cenário "de fora”. Segue o texto integral: 
Eu estava em Nápoles andando pela rua com o meu marido. E um homem disse bem alto para outro, ele queria que eu ouvisse: "É com mulheres como esta que contamos para reconstruir a Itália." Não reconstruí a Itália. Tentei reconstruir minha casa, reconstruir meus filhos e a mim. Não consegui. No entanto o italiano não estava fazendo galanteio, falava sério. Deus, fazei-me reconstruir pelo menos uma flor. Nem mesmo uma orquídea, uma flor que se apanha no campo. Sim, mas tenho um segredo: preciso reconstruir com uma urgência das mais urgentes, hoje mesmo, agora mesmo, neste instante. Não posso dizer o que é. (LISPECTOR, 1984, p. 103)

Por trás do comentário astucioso feito pelo homem italiano a Clarice, revela-se o olhar de uma época sobre um país com latente necessidade de reconstrução, de recomeço, fardo esse pesado demais para os ombros da escritora, que transborda em crônica. Observa-se a impressão que a instabilidade italiana causou em Clarice, que usou a fala do homem napolitano apenas como pretexto para discorrer sobre assuntos mais complexos e introspectivos, como a sensação de insuficiência na vida privada (a incapacidade de reconstruir a família), a necessidade de restauração e a urgência de mover-se em busca de algo.

No dia 13 de março de 1971, publicou-se a crônica "Bichos (I)", texto que discorre sobre a relação da escritora com animais e que rememora, no trecho abaixo, o cachorro Dilermando, de fato adotado por Clarice durante sua estadia na Itália:

Mulher feita, tive um cachorro vira-lata que comprei de uma mulher do povo no meio do burburinho de uma rua de Nápoles porque senti que ele nascera para ser meu, o que ele também sentiu em alegria enorme, imediatamente me seguindo já sem saudade da exdona, sem sequer olhar para trás, abanando o rabo e me lambendo. Mas é uma história comprida, a de minha vida com esse cão que tinha cara de mulato-malandro brasileiro, apesar de ter nascido e vivido em Nápoles, e a quem dei o nome rebuscado de Dilermando pelo que nele havia de pernosticamente simpático e de bacharel do começo do século. Desse Dilermando eu teria muito a contar. Nossas relações eram tão estreitas, sua sensibilidade estava de tal modo ligada à minha que ele pressentia e sentia minhas dificuldades. Quando eu estava escrevendo à máquina, ele ficava meio deitado ao meu lado, exatamente como a figura da esfinge, dormitando. Se eu parava de bater por ter encontrado um obstáculo e ficava muito desanimada, ele imediatamente abria os olhos, levantava alto a cabeça, olhava-me, com uma das orelhas de pé, esperando. Quando eu resolvia o problema e continuava a escrever, ele se acomodava de novo na sua sonolência povoada de que sonhos - porque cachorro sonha, eu vi. Nenhum ser humano me deu jamais a sensação de ser 
tão totalmente amada como fui amada sem restrições por esse cão. (LISPECTOR, 1984, p. 518-519)

No fragmento recortado, a narradora ironizou os "bacharéis do começo do século", com seus nomes elaborados e pernósticos, aos quais o cão "brasileiro" remetia. Durante os difíceis momentos passados em Nápoles, a autora conseguiu encontrar alegria e amor no sensível e companheiro cachorrinho mais do que em outro ser humano. Em 13 de agosto de 1945, Lispector contou para a irmã Elisa que "Dilermando, o cachorro, é uma delícia de cão e gosta de mim + do que a todos da casa. Me faz uma festa louca quando me vê de manhã, depois de uma noite de separação”. (LISPECTOR, 2007, p. 89). Em outra carta, essa de $1^{\circ}$ de setembro de 1945 , Clarice comentou para a irmã Tania que "O cachorro é a pessoa + pura de Nápoles... Se você visse como esta cidade é suja” (LISPECTOR, 2002, p. 73).

Linhas após falar sobre a pureza do cachorro nessa carta, Clarice desabafou à irmã: "Quanto a escrever a amigos do Brasil, querida, eles não me respondem... é ridículo, não é? não escrevo mais” (LISPECTOR, 2002, 76). Essa rápida passagem colabora para a compreensão dos sentimentos de solidão e abandono vivenciados pela autora em sua estadia no exterior, que a levaram a apoiar-se no tão querido Dilermando.

A continuação da crônica viria em 20 de março do mesmo ano, quando foi publicado "Bichos (Conclusão)", texto no qual Clarice lamentou o fato de ter-se separado do amado cachorro por conta de mal-entendidos com contatos da Suíça, próximo destino da escritora depois de Nápoles.

E eis que de repente fiquei agora mesmo com saudade de Dilermando, meu cão, uma saudade aguda e dolorida e desconsolável, a mesma que tenho certeza ele sentiu quando foi obrigado a viver com outra família porque eu ia morar na Suíça e haviam me informado erradamente que lá os hotéis, onde teríamos que permanecer algum tempo, não permitiam a entrada de animais. (LISPECTOR, 1984, p. 523)

Sente-se, com a leitura das crônicas, a solidão, a carência afetiva e o constante estado de não pertencimento de Clarice, que não possuía muitos contatos próximos na Europa, e que se sentia frequentemente exilada e esquecida pelos conhecidos brasileiros. 
Em 7 de agosto de 1971 foi ao público no Jornal do Brasil a crônica "Você é um número", que fala sobre a necessidade de quebrar os rótulos que são carimbados nos humanos ao longo de suas vidas, voltando-se para o amor e para Deus, que não são números. O texto não se refere à Itália especificamente, mas a autora remeteu à guerra para exemplificar a desumanização das pessoas, que são tratadas não como indivíduos, mas como meros números:

[...] Se há uma guerra, você é classificado por um número. Numa pulseira com placa metálica, se não me engano. Ou numa corrente de pescoço, metálica. Nós vamos lutar contra isso. Cada um é um, sem número. O si-mesmo é apenas o si-mesmo. (LISPECTOR, 1984, p. 573)

Os números tornaram-se tão essenciais para a vida que a escritora ironizou que iria "tomar aulas particulares de Matemática" para melhor compreendê-los (LISPECTOR, 1984, p. 572). Até na hora de morrer envolvem-se os números, que podem determinar em alguns casos quem vive e quem morre.

A reafirmação de uma individualidade ("o si-mesmo é apenas o si-mesmo") é ainda mais necessária em períodos de guerra, nos quais vidas únicas transformam-se em números, em um "eles" que se opõe a "nós", situação vista e sentida de perto por Clarice enquanto moradora de Nápoles. Contra essa situação, disse a narradora, sente-se a necessidade de protestar, mas logo percebe-se que "é inútil o protesto. E vai ver meu protesto também é um número" (LISPECTOR, 1984, p. 573). Nesse sentido, comenta a pesquisadora Valeria Rosito, no artigo “'Avisem-me se eu começar a me tornar eu mesma demais': Lispector nos anos de chumbo", que

a cronista revira, nos anos de chumbo no Brasil, as ruínas de um humanismo nefasto desde a sua mais remota invenção pelo homem. Levanta a lupa contra o instrumental sofisticado de reificação do humano e do não humano [...] (ROSITO, 2018, p. 10)

A também pequena crônica "Aldeia nas montanhas da Itália", publicada em 4 de março de 1972 no Jornal do Brasil, traz o sentimento de melancolia, tédio e tristeza que parecem ter sido experimentados pela escritora durante sua passagem pelo país, como sua correspondência da época desnuda. O texto conta que: 
Os homens têm lábios vermelhos e se reproduzem. As mulheres se deformam amamentando. Quanto aos velhos, os velhos não são excitados. $\mathrm{O}$ trabalho é duro. A noite, silenciosa. Não há cinemas. $\mathrm{Na}$ porta de casa a beleza das moças é a de ficar de pé no escuro. A vida é triste e ampla como deve ser uma vida na montanha. (LISPECTOR, 1984, p. 642)

Sem maiores distrações, como num cinema, os homens e mulheres continuavam a reproduzirem-se, em vida sempre dura e silenciosa, na aldeia das montanhas italianas, "como deve ser", segundo a narradora. O texto apresenta uma espécie de conformismo causado pela desesperança na existência de uma outra vida senão aquela de sempre.

É importante notar o quanto os acontecimentos vivenciados por Clarice na década de 1940 continuaram em seus pensamentos por muitos anos e, por mais que não tenham se materializado em textos publicados naquela época, surgiram tempos depois em seus escritos para o jornal. Como bem colocou Margareth Franklin:

Longe de ser uma iniciante descolada de vínculos com a realidade e afastada do compromisso social ou engajamento político, como boa parte da crítica acreditou durante anos, a jovem escritora esteve inserida no centro de uma rede intelectual influente e tomou parte em acontecimentos marcantes para a história brasileira. (FRANKLIN, 2010, p. 2)

Entendida muitas vezes pelos críticos e leitores como alienada e "não-social", Clarice Lispector revelou na correspondência e crônicas sua inquietação com os acontecimentos do mundo a sua volta, acontecimentos esses que ela vivenciou "em primeira mão" durante os anos passados na Itália em guerra.

\section{Considerações finais}

A leitura das cartas e crônicas de Clarice Lispector recortadas neste estudo, aliada à entrevista por ela concedida ao jornal $A$ manhã em 1945, colaboram para a (re)composição de quadros da Europa que foi conhecida pela escritora. A Segunda Guerra Mundial desnudou e potencializou problemas já existentes na Itália e no mundo, assim como dificultou a comunicação com familiares e amigos e cerceou a liberdade de ir e vir, aumentando o 
sentimento de solidão e a inquietação da escritora por saber quando poderia se reunir com as pessoas que lhe eram queridas.

Pesquisar esse material clariciano ajuda a demonstrar que, por trás da subjetividade e dita "alienação" social de Clarice Lispector, existe um pano de fundo marcado por acontecimentos históricos e pelas vivências pessoais da escritora.

Vê-se, portanto, que a própria Clarice se enquadrou nessa "surpresa literária no mundo de após-guerra" prevista por ela na entrevista concedida em 1945. Em suas crônicas e cartas, há também muita preocupação com questões sociais do mundo no seu entorno, como prostituição e pobreza, desigualdade social e desumanização do homem ao ser taxado apenas como um número e a latente necessidade de reconstrução do mundo moderno que se afigurava na época.

Mesmo que o período vivido em Nápoles não tenha sido fecundo em produções literárias "oficiais" (o mesmo não pode ser dito sobre a quantidade de cartas trocadas), as sensações e impressões da Europa em guerra embrenharam-se na escritora, que as utilizou posteriormente em diversos escritos enviados para o Jornal do Brasil.

\title{
CLARICE LISPECTOR'S WRITINGS ON WAR
}

\begin{abstract}
This paper aims to analyze Clarice Lispector's correspondences with her family and friends between 1944 and 1946, when the writer lived in Naples, Italy, just like the chronicles written by her about the World War II period. The aim of this study is to identify the historical background in which the author was inserted during her time in Italy, and the subjective dimensions of her relations with the world around her: to be a young foreigner of Jewish origins in the midst of the Nazi war, away from her family and friends. We aimed to understand which representations of Europe and war were made in her personal correspondence and in her later published texts.
\end{abstract}

KEYWORDS: Clarice Lispector; Correspondences; Chronicles; World War II.

\section{REFERÊNCIAS}

FRANKLIN, Margareth Cordeiro. Clarice Lispector e os intelectuais no Estado Novo. RevLet - Revista Virtual de Letras, Jataí: UFG. v. 2, n. 1. p. 111-130. 2010.

LISPECTOR, Clarice. A descoberta do mundo. Rio de Janeiro: Nova Fronteira, 1984. . Correspondências. Rio de Janeiro: Rocco, 2002. 
. Minhas queridas. Rio de Janeiro: Rocco, 2007.

MERON, Luciano Bastos. Memórias do front: relatos de guerra de veteranos da FEB. 2009. 160 f. Dissertação (Mestrado em História) - Faculdade de Filosofia e Ciências Humanas, Universidade Federal da Bahia, Salvador, 2009.

ROSITO, Valeria. "Avisem-me se eu começar a me tornar eu mesma demais": Lispector nos anos de chumbo. Revista Estudos Feministas, Florianópolis: UFSC, n. 26, p. 1-12, mar. 2018.

VIANA, Solena Benevides. Clarice Lispector fala de Nápoles. Rio de Janeiro: A Manhã, 2 de dezembro de 1945. $2^{\text {a }}$ seção, p. 1.

WALDMAN, Berta. Por linhas tortas: o judaísmo em Clarice Lispector. Arquivo Maaravi: Revista Digital de Estudos Judaicos da UFMG. Belo Horizonte: UFMG, v. 5, n. 8, p. 1-10, mar. 2011.

Recebido em: 01/10/2020.

Aprovado em: 30/12/2020. 